\title{
Textual mirrors and uncertain
} reflections: gender and narrative in L'Hiver de beauté, Les Ports du silence and La Rage au bois dormant by Christiane Baroche

Un roman est un miroir qui se promène sur une grande route. (Stendhal) (A novel is a mirror travelling along a highway.)

L'écriture est la possibilité même du changement, l'espace d'où peut s'élancer une pensée subversive, le mouvement avant-coureur d'une transformation des structures sociales et culturelles. (Cixous)

(Writing is precisely the very possibility of change, the space that can serve as a springboard for subversive thought, the precursory movement of a transformation of social and cultural structures.)

Christiane Baroche was acclaimed in France first as a short-story writer, although her œuvre as a whole now comprises not only short stories but also poetry, novels and essays. ${ }^{1}$ She has published many well-received volumes of realist 'slice of life' stories, beginning with Les Feux du large in $1975 ;^{2}$ several of her collections have been awarded literary prizes. The triptych Un soir, j'inventerai le soir, published in 1983 , is in a somewhat different vein, each of the three stories being original and playful treatments of the theme of myth, while functioning together as a comment on the diverse ways in which myth operates on identity formation. The motif of the mirror which structures this latter volume connects it with the novels I discuss in this chapter. ${ }^{3}$ Baroche's first novel Plaisirs amers was published in 1984, but it was her second, L'Hiver de beauté, first published in 1987, that really marked a new departure in her writing career. ${ }^{4}$ L'Hiver de beauté, which was repackaged in 1990 for the Folio edition and augmented with the addition of a postface by the author and new material (in the form of a short story), is, in one sense, a sequel to Choderlos de Laclos's 
eighteenth-century novel Les Liaisons dangereuses. The principal character of Baroche's novel is a rewriting of Laclos's intriguing Mme de Merteuil. Baroche picks up the character where Laclos left her in the last letter of Les Liaisons dangereuses: that is, having lost an eye because of smallpox, disfigured from the disease, ruined financially and socially as well as physically. In another sense, however, with the introduction of a twentieth-century female narrator-protagonist, L'Hiver de beauté is resoundingly contemporary, a powerful novel in its own right. Les Ports $d u$ silence and La Rage au bois dormant, both published in the first half of the 1990s, and L'Homme de cendres, which appeared in 2001, are likewise all substantial novels dealing with major contemporary and universal themes: life and death, war, memory, love. ${ }^{5}$

In L'Hiver de beauté, the motif of the mirror functions on several different levels and as such lays the foundations for the readings of both Les Ports du silence and La Rage au bois dormant which follow here. Deeply implicated in the construction of identity, the effects of the mirror motif are multiple, operating, in all these novels, in particularly creative ways on the representation of gender. In Les Ports de silence and La Rage au bois dormant, the mirror-object itself disappears, yet it still continues to function in figurative terms at the level of form. Stendhal's metaphor of the mirror, quoted in my epigraph, still holds true today, although it can of course only ever be a partial explanation of the way the novel works as a reflection of the society it portrays. Baroche's textual mirrors, however, operate in a rather different way. They proffer uncertain reflections which, on the one hand, pace Stendhal, are images of reality. On the other, however, following my second epigraph (Cixous's liberating description of literature as a precursor of social change), these novels also function as 'un ailleurs', an 'elsewhere' or 'somewhere else', in which it is possible to envisage escaping from the dominant scheme of gender identities and sexual politics. ${ }^{6}$

Three moments highlight the importance of the mirror in L'Hiver de beauté:

J'ai levé les yeux vers le grand miroir de Venise qui renvoie mille lumières pour une, qui m'a renvoyé dix mille morts pour la ruine de mes traits. A vingt-cinq ans, j'entrais dans l'hiver de beauté. (p. 15)

(I raised my eyes to the large Venetian mirror, which reflects back a thousand images instead of one. My ruined face stared back at me and I died a thousand deaths. Twenty-five years old, and I had already entered the winter of my beauty.) 
'Je me contemple. Je n'ai jamais fui la vérité, tu le sais bien, ou si peu de temps...'[...]j'étais redevenue, ou plutôt j'étais rentrée dans une humanité banale,j'étais laide, c'est tout. (p. 50)

('I am contemplating myself. I have never tried to deny the truth, as you well know, or only fleetingly. . . [. . . I I was, or rather I had become, ordinary, I was just ugly, that's all.)

Isabelle se regardait dans le miroir de l'Etude qu'elle avait emporté [...] Je ne suis pas belle, je suis mieux que cela. Vivante. (p.318)

(Isabelle looked at herself in the Study mirror that she had brought with her [...] I'm not beautiful, I'm better than that. I'm full of life.)

On the first occasion, Baroche's Mme de Merteuil-character, now named Isabelle, looks into the Venetian mirror at her sister's house and is confronted with multiple images of the full horror of her scarred and disfigured face. Some months later, when the scabs from the smallpox have disappeared and the worst of the scarring has begun to fade, she contemplates herself in a similar mirror in her own house, concluding that she is no longer the frightening monster she once was - she is now simply ugly. And at the end of Baroche's novel, on board ship, about to embark on a new life in the New World, Isabelle once again looks into the mirror that she has brought with her, and discovers that inner vitality is more seductive than superficial beauty. These three occasions when Baroche's Isabelle (the exMme de Merteuil) looks at her reflection in the mirror mark important stages both in her recuperation from the living death in which Laclos had left his character and in the reconstruction of Isabelle's own identity that Baroche's novel effects.

The mirror, then, has a primary role in the construction of identity in L'Hiver de beauté, but not only as content: the mirror is also central to the form of the novel. Not only does L'Hiver de beauté exist in an explicit intertextual relationship with Laclos's Les Liaisons dangereuses, setting up reflections and echoes between eighteenth and twentieth centuries, but it is also a metafiction. The twentieth-century character Queria reads the diaries Isabelle has written in order, in turn, to write a book about the eighteenth-century woman's life. Thus, the Venetian mirror, framed by small mirror panes, in which Isabelle sees her ruined face reflected a thousand times over, becomes a trope for the multiple mirroring which structures Baroche's novel: writing about writing, writing about reading, reading about writing, reading about reading. The result is a series of 
reflections between writers (Baroche, Laclos, Queria, Isabelle) and between readers (Baroche (especially via the postface which tells of her reading of Laclos's novel), Queria, readers of Queria's work within the novel and Baroche's own readers).

Dual narratives create a system of alter egos and elicit a dialogue between characters, between historical periods, between text and reader. None the less, this is no straightforward mise-en-abyme, and it is here that the comparison between the Venetian mirror and Baroche's text begins to founder. In the eighteenth-century, Venetian glass was the clearest it was possible to obtain, but the reflections Baroche's novel relays to the reader are uncertain, unstable and fragmented. Cloudy images permeate the text - harbour mists, flickering candlelight, dimly lit rooms, grey seas, soapy water - and these images echo and reinforce the fluid and uncertain nature of the narrative. Narration, reconstruction and fictionalisation alternate and interweave in a complex way. Narration is in both the first person and third person, and, despite typographical distinctions, it is at times difficult to tell who is speaking - eighteenth-century Isabelle or twentieth-century Queria. Just as Queria pieces together Isabelle's life, Baroche's readers have to construct their own versions - of Isabelle, of Queria and of other characters in the novel. Isabelle comes into being within the diegesis as a combination of what Queria's historical research unearths and the woman Queria imagines Isabelle to be. For Baroche's readers, the character Isabelle is also likely to carry traces of her intertextual self and other, Laclos's formidable Mme de Merteuil. Queria (the twentieth-century woman) is a shadowy persona who becomes a character in her own right only in the course of reconstructing Isabelle as a powerful, empowering figure in her book.

The uncertainty that is thus inscribed into the very texture of Baroche's text is none the less particularly fruitful and enabling, especially as far as gender is concerned. Seductive albeit ugly and disfigured women; emotional men; independent, active and violent women; passive men; women as desiring subjects; men as sexual objects; a raped woman emerging triumphant from her ordeal: ${ }^{7}$ these are some of the ways in which conventional gender identities are undermined in L'Hiver de beauté. The Mme de Merteuil that Laclos originally created was like a siren of classic Greek mythology - fascinating men and leading them to their destruction. Baroche's Isabelle is singularly different. She becomes 'la sirène borgne' (the one-eyed siren), assuming an identity which includes her disfigurement within a seductive persona: like the sirens, Isabelle's singing fascinates 
men but rather than destroying them, it moves them to tears, putting them in touch with their own emotions. Here, women are described as 'un peu virile(s)' (slightly virile) and men 'un peu féminin(s)' (slightly feminine). The 'un peu' (slightly) is crucial: it signifies that men's so-called 'femininity' co-exists with conventional masculinity, and women's 'masculinity' with their more traditional femininity. Baroche's men have qualities that are usually assigned to the feminine, but their femininity is considered to enrich their masculinity rather than to take anything away from it: they are neither emasculated nor are they androgynous. Thus the binary opposition of masculinity and femininity, that works to imprison real men and women in stereotypical gender roles, is clouded in Baroche's novel and a different dynamic between the terms is accommodated within individual characters.

None the less, despite the fact that stereotypical gender identities are problematised in L'Hiver de beauté, the narrative does not offer any clearly defined alternatives, and this is actually where the strength - and the generosity - of Baroche's writing lies for readings that are attentive to gender. Indeed, it is not so much the actual representations of men and women as the uncertainty that suffuses their portrayal that works to bring about a compelling questioning of gender identities in Baroche's work. Thus her readers are left to speculate, for example, on what the different, slightly feminine, sort of masculinity, that Baroche's novel points to, might actually be like in practice.

In the two later novels Les Ports du silence and La Rage au bois dormant, the literal Venetian mirror of L'Hiver de beauté has completely given way to complex systems of textual mirroring. Both novels are metafictional (they are themselves about reading and about writing), both have multiple narratives, in both, layers of textuality work explicitly to problematise single meanings and to contribute to the open-ended nature of the texts. As in L'Hiver de beauté, narrative uncertainty is a prime player and it impacts on the portrayal of gender in similar ways. Although binary oppositions are dismantled, multiple narratives work against any fixing of alternative identities. The two main characters in Les Ports du silence, Jaime and Elodie, are seen through the eyes of a number of different characters, as well as their own, so that the picture that the reader puts together from these various perspectives is not only necessarily fragmented but also contradictory. Moreover, Jaime and Elodie mirror the principal characters in L'Hiver de beauté: like Queria and Isabelle, Elodie is both 'laide' (ugly) and 'vivante' (full of life), and she is a woman who is both active and passive, masculine and feminine. Jaime, described as 'a real man' by his house- 
keeper, is also 'un peu féminin' (slightly feminine) - sensitive, a dreamer, passive.

In La Rage au bois dormant, the mirroring motif works rather differently. While, in L'Hiver de beauté, it is as if Queria and Isabelle each have different sides of the same face, so it is, in La Rage au bois dormant, that the two principal women characters, Adèle and Judith, manifest two different sides of women's identity. Similar pairings are to be found elsewhere in Baroche's novels - in Isabelle and her sister Madeleine in L'Hiver de beauté and in the sisters Marthe and Magdelène in Les Ports du silence. In La Rage au bois dormant, Adèle, first a prostitute, then a wife and mother, is largely passive and unquestioning. For example, she remains blissfully ignorant of her husband's illegal business activities until long after his death. This is all the more surprising since, not only was the couple forced to flee to South America because of it, but also Adèle herself is a real gossip - at least as far as other people are concerned. Judith, on the other hand, is a passionate, independent and active woman: also a wife and mother, she is, however, first a committed resistance fighter, and then a successful business woman, her work and her love of horses sustaining her in the face of repeated tragedy. None the less, the relationship between the two women ultimately complicates any straightforward mirroring structure and works against the fixing of their identities, as it becomes clear that gossip, fantasy and embroidered memories are part and parcel of the life stories that are being told within the diegesis. Adèle does not really know much about Judith; the stories she tells are attempts to save her own life story from the failing memory of old age; they are one set of stories among many possible stories, the many possible narratives of what it means 'to be a woman'.

It is in (hetero)sexual politics that the radical potential of the gender identities suggested in Baroche's novels can be seen most clearly. Heterosexuality has long been critiqued as a normative institution by various forms of feminism and more recently by queer theory, ${ }^{8}$ but contemporary feminist analyses of heterosexuality itself that take on board changing practices and the diversity within it have been fewer. ${ }^{9}$ Sexual politics are a key determinant of individual heterosexual relations and the ways in which gender identities are lived in turn impact on social and sexual relations between men and women. In Laclos's Les Liaisons dangereuses, Mme de Merteuil is a female Don Juan, and thus, for a while at least, reverses traditional sexual politics. Baroche's novels go further, and, rather than simply reversing the binary oppositions man/woman, masculine/feminine, active/passive, they disrupt them, as we have seen, and relationships 
between men and women go against the grain. Leaving behind the rigid etiquette and hierarchies of French court society (Les Liaisons dangereuses) and the conventions and proprieties of bourgeois Rotterdam (L'Hiver de beautê), Isabelle and the man she loves (Armand-Marie) will, it is intimated in the latter novel, develop their relationship, each on their own terms. A new life in the New World, to where they are bound at the end of the eighteenth century, functions as a promise of different possibilities for living out both social and sexual relations.

Similarly, in the same novel, Queria embarks on her own love affair (with Barney) at the same time as she embarks on a whole new way of life. She flies to South America to be with him, but this is no romantic walk into the sunset, since, before leaving, she makes firm plans for a new career on her return. The couple's rendez-vous on the beach at Rio problematises romantic clichés further. Each enjoying their solitude, they defer the moment of their meeting which in romantic genres would have been a conventional 'happy end' in itself. Queria wants Barney to love her, 'mais pas trop', to be there, 'mais pas trop' (p. 289) (but not too much). The sexual politics between Barney and Queria that are sketched out in Baroche's novel are thus sufficient to signal that their relationship will not conform to conventional patriarchal formulas, but the way in which this is to be lived out is not actually represented in the novel. It is left for the reader to work with the pointers in the text.

Les Ports du silence arguably gives its readers a little more practical detail on the subject of heterosexual sexual politics. The relationship between Jaime and Elodie is suffused with silence and mutual respect: ' $\mathrm{je}$ reste où je suis, je ne franchis pas sa frontière...' (p. 82) (I stay where I am, I don't invade her territory. ..). They are 'deux solitudes' (p. 254) (two solitary people), a 'fils' and a 'fille du vent' (pp. 127, 207) (son and daughter of the wind), independent, with different lives, different desires. Jaime loves Elodie for her vitality, for the life she has in her; Elodie, in turn, will love Jaime 'une fois pour toutes' (p. 254) (once and for all). They love but they do not need - each other, anyone. Again, here, there is little explicit detail, but there is no sense given in the text that they depend on each other for anything. None the less, they have a child; Jaime leaves and returns; they have another child; but never do they constitute a conventional nuclear family. Although it is Jaime who goes away to work and Elodie who stays behind, a situation that may, on the face of it, seem to reinforce conventional gender roles, this arrangement is none the less open to positive feminist readings. In fact, the traditional male/female split between active and 
passive or between public and private does not apply. Nor is it just reversed in the way it is elsewhere in the same novel - in the opposition between the busy activity of Jaime's housekeeper, Louise, and the immobility of her passive, inert husband. Elodie has her own life and work. Moreover, the parenting arrangements, love and mutual respect between Elodie and Jaime are shared by another woman, Flore. Yet, even so, the three adults do not form a ménage à trois. When Jaime returns from travelling once and for all, the three of them continue to live separately: 'Le bonheur. Pas tout à fait celui qu'on pratique, mais quoi! En plus, il n'y a rien à en dire, les gens heureux n'ont pas d'histoire' (p. 270) (Happiness. Not exactly the way we'd go about it, but so what! Anyway, there's nothing more to say, happy people have no story). The narrator's gossipy tone, the uncertainty that surrounds the relationships being commented on and the silence about the way of life that is gestured at here are all part of the fabric of the narrative. They make space for the reader's interpretation even as they offer scope for the characters to live differently within the diegesis. At the end of the novel, we are left with the possibilities of the different kinds of sexual politics and alternative family arrangements that are hinted at. The reader must flesh out the representation from the bare bones sketched out in the text. Moreover, the 'alternative' nature of that sketch may well lead us to speculate on the sort of gender identities that will become possible for the next generation, in the persons of the two young daughters of Jaime and Elodie.

In Les Ports du silence, therefore, Baroche points optimistically to workable alternatives to the nuclear family, and indeed, in the wider breadth of her work, the number of women who for various reasons mother children who are not their own is noteworthy. The diffusion of mothering roles and relations in Baroche's fiction is significant and forms a creative input into contemporary feminist analyses of changing theories and practices of parenting. Yet positive portrayals of alternative parenting in Baroche's novels are certainly not restricted to heterosexual arrangements. Homosexual or bisexual parenting is not uncommon in her work and includes, as the gossipy narrators of Les Ports du silence would have it, Elodie's own adored (and adoring) father, Basile: 'Il n'a pas eu d'enfant de son sang. Des bruits ont couru qu'il ne pouvait pas, qu'il y a des mariages commodes quand ce sont les garçons qu'on aime... En vérité, Basile ne voulait pas plus des gars que des filles, même s'il a usé des deux à ce qu'on murmure' (p. 183). (He had no children of his own. They said that he couldn't, that marriage is convenient for men who like boys... In truth, 
Basile didn't want boys any more than girls, even if, as the story goes, he'd made use of both.) Basile is not Elodie's biological father, but he married her mother, brought her up and she carries his name, and as Basile himself argues: 'un enfant, c'est un enfant. Et le père, celui qui l'élève ... "Qu'estce que c'est qu'une semence, Louise? Trente secondes de plaisir, et encore c'est parce que je ne trouve pas d'autre mot. Tandis que vingt ans de patience, de soins, d'amour. .."' (p. 219) (a child is a child. And the father is the one who brings her up ... "what is fertilisation, Louise? Thirty seconds of pleasure, and I use that word because I can't find a better one. While twenty years of patience, of care, of love...'). Here, biological paternity is contrasted with years of fathering, immediate sexual pleasure with long-term care and affection, and found lacking. ${ }^{10}$

Parenting by homosexual men is also to be found in Baroche's $L a$ Rage au bois dormant. Here, Judith is marked for life by the hatred shown her by her father, who, as she discovers when she finds him in bed with another man, indeed uses marriage and fatherhood as a respectable cover for his homosexual activities. Judith's father serves as an example of negative homosexual parenting, but this is set against a positive one in the same novel. Two other gay men (Bernard and François Esposite) become Judith's 'chosen family'. Not only does Judith choose, as a teenager, to live with them herself but she also chooses to leave her much-loved young son, Emmanuel, in their care during the greater part of his childhood. The arrangements Judith has with the Esposites are particularly interesting in terms of the implications they have for gender identities as well as for the intrinsic issue of gay parenting itself. Controversially, the term 'mothering' is used in the narrative, albeit passingly, to describe the two men's parenting role: 'Pour qui d'autre les Esposite feraient ce qu'ils font, du maternage?' (p. 249) (For who else would the Esposites do what they do - the mothering?) However, the context of the enunciation is uncertain. Because of the multiple narrative and the metafictional layering of the text, it is impossible to tell for certain from which character, or even from which historical period, the term 'mothering' originates. Moreover, the structure and style of Baroche's narrative means the reader cannot know whether this description is just gossipy, or whether it is homophobic (implying that gay men are like women), or, alternatively, whether it makes direct reference to the type of care the Esposites provide (although there are very few details given in the text of Emmanuel's life with the two men).

If, however, this chosen family arrangement is to be set up as an interesting alternative to the norm - or normativeness - of the heterosexual 
nuclear family, the key question to ask must be to what extent the example of stable family life provided by the Esposites in La Rage au bois dormant differs from that norm. The first point to note is that the most telling comparison in Baroche's novel is not actually between homosexual and heterosexual parenting, but between different kinds of parenting by homosexual men. Moreover, aside from the fact that Judith's own (homosexual) father fathers (negatively) precisely within what is overtly a standard nuclear family set-up, if the Esposites can be perceived to form a nuclear family, it is in a reconfigured version. As a couple, Bernard and François Esposite do not assume conventional heterosexual gender roles or functions: neither one of them is more 'masculine' or more 'feminine' than the other; nor does one of them take on the conventional paternal role and the other the maternal one. Instead, according to the narrative, they both mother - which means that in La Rage au bois dormant, Judith's son Emmanuel arguably has three mothers... And two of them are men!

As I have argued throughout this chapter, Baroche's novels, shot through with uncertainty, offer food for thought, rather than providing fixed and complete representations. In itself, the reference to the care the Esposites give Emmanuel as mothering raises a series of questions about gender and parenting, although it does not go as far as answering them. Can we really use the term 'mothering' for the care men give to children? What does it actually mean to say that men mother? What are the differences between mothering by men and fathering? What then are the implications for heterosexual parenting, for gay and lesbian parenting? What does 'mothering' mean these days anyway? What will it come to mean in the future?

Despite some challenges to the novelistic conventions of character, chronology and form, Baroche's novels are not, however, obviously radical, revolutionary works. Instead, her writing is resoundingly realist and, in many respects, conforms to convention. In terms of content, patriarchy as a system is certainly not dislodged, nor is it much shaken, although, as I have argued here, frequently the dominant scheme of gender identities, of sexual politics, of family arrangements is subverted by individual practice. The author herself maintains that the men and women she creates in her fiction and the relationships between them are simply reflections of changing reality, based on the lives she sees around her. ${ }^{11}$ Hence, on the one hand, Baroche's fiction shows us the value of individual agency: it $i s$ possible to live our gender identities differently; it is possible to work out alternative relational models. Moreover, individual interventions into the social 
order such as those inscribed in her novels can gradually modify attitudes, practice, social structures, on a wider scale. On the other hand, Baroche's novels in themselves foreground the reader's part in contributing to the representations they adumbrate. The textual mirroring, in the three novels discussed in this chapter, functions both as a mise-en-abyme that impacts on the text-reader relationship and as a vehicle of uncertainty that is inscribed into the narrative. These functions work together to engage the reader's interaction with the text. The most creative challenge to conventional gender identities comes not simply in the way the characters are represented in Baroche's texts, nor only in the readers' interpretations of them, but rather in the potential for speculative readings engendered by the mirroring structure of the text.

Thus, Baroche's novels demonstrate that fiction and reality are interdependent, but the multiple mirroring and uncertainty that are a key part of their character go even further than this and have a twofold effect. On the one hand, these texts act as mirrors of reality, reflecting, however, not only the dominant order of things, but also newly emerging experiences and innovative practices. On the other hand, the uncertain reflections they offer mean they also act as Cixousian textual 'elsewheres', pointing to alternative (still-to-be-represented) concepts and ways of living, of loving, of being. Compared with the arguably more utopian but equally empowering visions of, say, Cixous's own textual elsewheres, Baroche's more realist writing has certain strengths. This is because, although the alternative forms of gender identity discussed here are never fully represented, they are eminently representable, and as such suggest new directions and examples of what future practice might become.

As sociologist Stevi Jackson argues, in order for change to come about in reality, we need 'to imagine social relations being radically other than they are' (Heterosexuality in Question, p. 182). ${ }^{12}$ Baroche's thoughtprovoking novels initiate this sort of imagining. Her Venetian mirrors and the uncertainty of their multiple reflections are both provocative and full of promise, initiating a sort of dialogue with the reader, facilitating a speculative engagement with the text. Baroche's work does not offer set alternatives that may well be as alienating to some readers as they are empowering to others. Rather, it challenges us to think, to rethink gender identities, loving relationships and sexual politics for the contemporary world in which we live. 


\section{Notes}

1 See, for example, the special issue of the journal Sud devoted to Baroche, "A la tour abolie: rimes intérieures II', Sud, 105 (1993).

2 Christiane Baroche, Les Feux du large (Paris: Gallimard, 1975).

3 Christiane Baroche, Un soir, j’inventerai le soir (Paradou: Actes Sud, 1983). See Gill Rye, 'La ré-écriture mythologique: tradition, originalité et identité dans $U n$ Soir, j'inventerai le soir de Christiane Baroche', in Johnnie Gratton and JeanPhilippe Imbert (eds), La Nouvelle hier et aujourd'hui (Paris: L'Harmattan, 1997), pp. 159-65.

4 Christiane Baroche, Plaisirs amers (Paradou: Actes Sud, 1984); L'Hiver de beauté (Paris: Gallimard, 1987; extended Folio edition, 1990).

5 Christiane Baroche, Les Ports du silence (Paris: Grasset, 1992); La Rage au bois dormant (Paris: Grasset, 1995); L'Homme de cendres (Paris: Grasset, 2001).

6 For the text as an ailleurs, see Hélène Cixous and Catherine Clément, La feune Née (Paris: UGE, 1975), p. 132; The Newly Born Woman, trans. Betsy Wing (London: I. B. Tauris, 1996), p. 72.

7 For a discussion of the rape episode in the context of reading in/of Baroche's novels, see Gill Rye, Reading for Change: Interactions between Text and Identity in Contemporary French Women's Writing (Baroche, Cixous, Constant) (Bern: Peter Lang, 2001), pp. 79-81, 107-8, 190-1. For a wider discussion of Baroche's women characters, see Michael Worton, 'Le chant de la sirène: les romans de Christiane Baroche', Sud, 105, 73-85.

8 Seminal texts for this kind of critique are Adrienne Rich, 'Compulsory heterosexuality and lesbian existence', Signs, 5 (1980), 631-60; Judith Butler, Gender Trouble: Feminism and the Subversion of Identity (London: Routledge, 1990).

9 But see Lynne Segal, Straight Sex: The Politics of Pleasure (London: Virago, 1994), which argues for the need to consider heterosexualities in the plural; Nancy Chodorow, Femininities, Masculinities, Sexualities: Freud and Beyond (London: Free Association Books, 1994), which accommodates plurality; Stevi Jackson, Heterosexuality in Question (London: Sage, 1999), which identifies the importance of seeing heterosexuality 'as a site of struggle and contested meanings for those who are heterosexual as well as those who are not' (p. 165).

10 See also Elisabeth Badinter, XY: de l'identité masculine (Paris: Odile Jacob, 1992), who in her discussion of fatherhood reiterates this thus: 'Nous entendons par "père", non seulement le géniteur de l'enfant, mais tout substitut paternel qui donne amour et soins à un enfant' (p. 247) (We understand by 'father', not only the child's biological parent, but also all paternal substitutes who love and take care of a child).

11 Unpublished interview with Gill Rye at Cerisy-la-Salle (26 August 1995).

12 It is noteworthy that the importance of being able to imagine difference is recognised here even from a sociological and materialist feminist perspective such as Jackson's. 